\title{
RESOURCE REQUIREMENTS FOR NATIONAL ACTIVE SURVEILLANCE PROGRAMMES OF HIGH IMPACT EXOTIC PESTS IN NEW ZEALAND
}

\author{
S. GANEV and M. BRAITHWAITE \\ National Plant Pest Reference Laboratory, Ministry of Agriculture and Forestry, \\ P.O. Box 24, Lincoln, New Zealand \\ Corresponding author: GanevS@maf.govt.nz
}

\begin{abstract}
Organisms that are new to New Zealand are detected every year. These range from benign or saprophytic to significant pests. Currently, detection of exotic organisms relies on a combination of public submissions, reporting from research scientists and limited planned surveillance programmes. With the exception of the fruit fly surveillance programme, the Ministry of Agriculture and Forestry Biosecurity Authority (MAFBA) does not undertake active surveillance programmes for high impact exotic pests of horticulture and agriculture. This is seen as a potentially significant deficiency. The National Plant Pest Reference Laboratory (NPPRL) was commissioned by MAFBA to conduct pilot surveys of twelve high impact exotic pests to determine the resources required to plan, carry out field surveys and conduct laboratory identifications. The surveys were statistically designed to enable early pest detection and hence, maximise the probability of pest eradication. Pest selection was based on pest reputation, biology, epidemiology and the use of various diagnostic techniques to provide a variety of potential scenarios. This paper presents details of the sampling, statistical methods and resources that were used to compile information on active surveillance programmes for each pest. Keywords: biosecurity, high impact exotic pest, surveillance, eradication.
\end{abstract}

\section{INTRODUCTION}

The Ministry of Agriculture and Forestry (MAF) has been conducting crop surveys for a number of years. Initial surveys concentrated on examining specific crops for all pests and diseases present (Bejakovich et al. 1998; Dymock \& Holder, 1996; Braithwaite et al. 1998). Recently, surveys of high impact exotic pests (HIEPs) were conducted to determine the resources required for planning, carrying out field surveys and laboratory identifications in order to provide a high probability of detection of the pest if present. These HIEPs were defined as those with potential to cause severe economic losses in specific crops should they become established in New Zealand. A variety of different pests were selected to provide a range of life cycles and epidemiology on which to determine the scope of potential active surveillance inputs.

The primary aim of these surveys was to collect data about the time taken and costs required to survey for various pests and then extrapolate the data to estimate the resources required for a national survey for each pest. Early detection of these pests is critical for successful eradication.

\section{Pest and site selection}

\section{METHODS}

Pilot surveys occurred over two successive seasons from 2000 to 2002. The targeted pests were asparagus rust (Puccinia asparagi), citrus canker (Xanthomonas axonopodis pv. citri), karnal bunt (Tillitea indica), kanzawa mite (Tetranychus kanzawai) and Sharka 
(Plum pox potyvirus) in the 2000-2001 season, and yellow peach moth (Conogethes punctiferalis), apple rust (Gymnosporangium asiaticum), Asian pear rust (Gymnosporangium juniperi-virginianae), apple brown rot (Monilinia fructigena), glassy-winged sharpshooter (Homalodisca coagulata), Soil-borne wheat mosaic virus and Pierce's disease (Xylella fastidiosa) in the 2001-2002 season. Tetranychus kanzawai has recently been synonymised with $T$. hydrangeae, which occurs in the USA (Navajas et al. 2001). The number of sites surveyed for each pest ranged from two for soilborne wheat mosaic virus to 64 for the glassy-winged sharpshooter (Table 1). Survey sites were selected in areas of significant target crop production, in climatic zones suitable for pest development and areas of high risk of importation of pests, such as adjacent to ports. A total of 221 sites were surveyed throughout New Zealand over two seasons (Table 1).

TABLE 1: The number of survey sites within each region'.

ND AK WO BP GB HB TK WI WN MB NN NC MC SC CO DN SL Total

2001 Survey sites

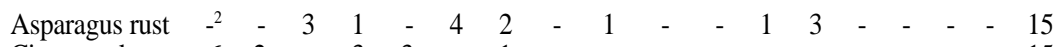

$\begin{array}{llllllllllllllllllll}\text { Citrus canker } & 6 & 2 & - & 3 & 3 & - & 1 & - & - & - & - & - & - & - & - & - & - & 15\end{array}$

Kanzawa mite $2 \begin{array}{llllllllllllllllll} & 2 & 6 & 6 & 4 & - & - & 2 & - & - & - & 3 & - & - & - & - & - & -\end{array}$

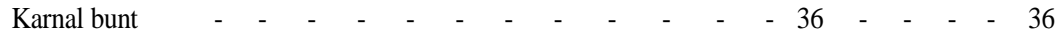

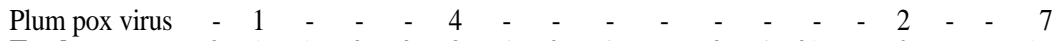

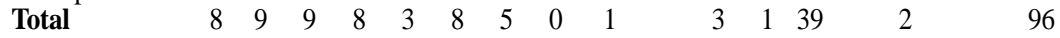

\section{Survey sites}

\begin{tabular}{|c|c|c|c|c|c|c|c|c|c|c|c|c|}
\hline $\begin{array}{l}\text { Brown rot; apple - } \\
\text { pear rust }^{3}\end{array}$ & $-\quad-$ & 1 & - & - & 8 & - & 2 & 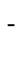 & 1 & 6 & & \\
\hline $\begin{array}{l}\text { Apple/Asian pear - } \\
\text { ust on Juniper }\end{array}$ & - & 1 & 1 & - & 2 & - & 1 & & & 1 & 1 & \\
\hline $\begin{array}{l}\text { winged } \\
\text { looter }\end{array}$ & 151 & - & 3 & 2 & 2 & - & & & & 3 & & \\
\hline ease & - & - & - & ? & 5 & & & & & & & \\
\hline wheat - & - & - & - & - & 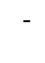 & - & - & 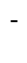 & & - & 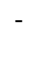 & \\
\hline Yellow peach moth - & 2 & 1 & 2 & - & 4 & 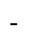 & 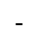 & & & - & & \\
\hline otal & 19 & 3 & 6 & 4 & 21 & & 3 & & 6 & 10 & & \\
\hline
\end{tabular}

\begin{tabular}{lllllllllllllllllll} 
Grand total & 9 & 62 & 12 & 14 & 7 & 29 & 5 & 3 & 1 & 6 & 13 & 4 & 45 & 1 & 7 & 2 & 1 & 221 \\
\hline
\end{tabular}

${ }^{1}$ Regions as described by Crosby et al. (1998) (ND=Northland, AK=Auckland, $\mathrm{WO}=$ Waikato, $\mathrm{BP}=$ Bay of Plenty, $\mathrm{GB}=$ Gisborne, HB=Hawke's Bay, TK=Taranaki, $\mathrm{WI}=$ Wanganui, $\mathrm{WN}=$ Wellington, $\mathrm{MB}=$ Marlborough, $\mathrm{NN}=\mathrm{Nelson}, \mathrm{NC}=\mathrm{North}$ Canterbury, $\mathrm{MC}=$ Mid Canterbury, $\mathrm{SC}=$ South Canterbury, $\mathrm{CO}=$ Central Otago, $\mathrm{DN}=$ Dunedin and $\mathrm{SL}=$ Southland).

${ }^{2}$ Site not surveyed during that particular survey or year.

${ }^{3}$ Brown rot and apple/Asian pear rust surveys were done simultaneously on apples and pears.

Grower organisations and local councils were contacted to obtain lists of growers (orchardists and nurserymen) and public gardens. Survey sites were then selected randomly from these lists. Owners of individual properties were contacted to gain approval to survey and obtain data on plant numbers, types of crops and varieties grown, plant spacing, growing systems, and property location and ownership. Wherever possible, a detailed site plan of each property was obtained. 


\section{Sampling model}

A model was developed to calculate the likelihood that an infected site will be detected in the survey based on the number or proportion of infected sites in the country, the proportion of plants infected at these sites, the likelihood that the infection will be detected if an infected plant is sampled, the number of sites visited and the number of plants sampled at each site. The model then calculates the likelihood that the pest or disease will be detected in the survey if the specified proportion of sites and plants are actually infected. A binomial distribution is used if the number of sites in the country or the number of plants at a site is very large; a hypergeometric distribution is used where the number of sites or plants is smaller. Table 2 outlines the number of sites and plants that would need to be sampled in order to detect plum pox if 1 of 535 orchards in New Zealand has at least $5 \%$ of trees infected with a $95 \%$ probability. The likelihood of an infected tree being correctly identified as such when sampled was assumed to be $45 \%$, based on the chance of taking an infected sample from an infected, symptomless tree and the chance of an infected sample testing positive by ELISA in the laboratory. These data were used to extrapolate the time and costs required for a nation-wide survey (excluding any travelling time) for each target pest.

\section{TABLE 2: Analysis of plum pox virus detection probabilities in commercial orchards at different detection rates.}

Probability of detecting the first infected orchard

$95 \%$

Assumptions

Number of orchards infected in NZ

Chance of taking an infected sample from infected, symptomless tree

Chance of infected sample testing positive in lab

Probability of correctly identifying an infected sample

Proportion of trees in a symptomless orchard infected

Probability of detecting at least one infected tree at an orchard - binomial

Percentage of orchards infected

Confidence of finding at least one infected orchard in survey - hypergeometric

\section{Model output}

Total orchards sampled

\section{Field and laboratory work}

Methods for plant examination and gathering data during inspections for each target pest, were tailored to the biology, epidemiology and host specificity of each organism. Sample points were identified for each pest and consisted of either a single plant (e.g. in apple orchards), small groups of plants (e.g. in wheat crops) or whole rows (e.g. in asparagus crops). At each site the times taken to prepare for the survey, inspect the plants, record results, collect samples, decontaminate gear and conclude the survey were recorded. Hygiene procedures to prevent any spread of pests between sites were strictly adhered too. The times taken to access and process the samples and identify the microorganisms were recorded. Costs associated with all aspects of the survey were noted. Field samples were not tested for plum pox so laboratory testing times and costs were estimated from post-entry quarantine testing for the disease.

\section{RESULTS AND DISCUSSION}

None of the selected HIEPs was detected during surveys of 221 sites throughout New Zealand over two years. However, detection was not expected since all pests were significant exotic organisms not known to be present in New Zealand. In addition, sample numbers were low statistically. 
Depending on the pest, sampling relies on visual inspection and collection of suspect material, or in the case of plum pox, of randomly collecting leaf samples for ELISA testing. Diagnostic testing for various diseases ranged from simple visual or microscopic examination through to molecular techniques, which would be used to confirm the presence of a disease. The time taken to locate and inspect a sampling point varied from 1.09 minutes (for juniper plants in a nursery) to 42 minutes (chestnut trees in a park) (Table 3 ). This variation was a result of the methodology used, the sampling intensity and the total area required to be inspected. In general, the time taken to locate and inspect individual plants did not vary much between the different hosts surveyed. This is probably a result of the actual host inspection time being small compared to the time required to walk and locate the plant. The exception was where whole rows were inspected (asparagus) or a small number of plants were inspected within a large area (e.g. surveying chestnuts in parks for yellow peach moth), both of which required considerably more time.

To extrapolate the data to a full national survey, the sampling model allowed the sample points and number of survey sites to be varied. This enabled detection of the target pest with a 95\% level of confidence. Time and costs were also calculated for a $99 \%$ probability of detection (data not presented). Examining the extrapolated data, the number of hours required to inspect (including pre- and post-inspection times) varied from 0.8 (small number of hydrangea plants in a home garden) to 85.4 (large chestnut trees in a commercial orchard). This large variation in sampling time reflects the diverse range of pest types, sites and sampling techniques used to provide a uniform confidence of pest detection.

The time associated with processing and identifying pests in the laboratory varied depending on the pest and the protocols used for identification (complete data not presented). For example, it is estimated that 69,550 samples would need to be laboratory tested by ELISA for a $95 \%$ probability of detecting the first infection of plum pox in an orchard. These samples would require 20,865 hours of processing time.

The estimated total costs of surveillance and testing (excluding travel times) are presented in Table 3 and are calculated at \$12/hour for field labour and \$60-100/hour for laboratory costs and consumables. The high costs for plum pox and soil-borne wheat mosaic virus are associated with costly laboratory testing. Large numbers of samples would be required to be tested as plants can be symptomless and the serological methods required are time consuming and use expensive reagents. The costs for molecular testing of large number of samples for Pierce's disease and citrus canker are not included in the cost estimates. Therefore, survey costs could be considerably higher where large numbers of samples need to be tested.

Surveillance for serious exotic pathogens is of concern to other countries. For example, surveys for exotic pathogens have been conducted for Phytophthora ramorum in England and Wales in 2002 (Lane et al. 2003), and Australia conducted surveys of East Timor in 2000 to identify potential threats to Australia (Weinert 2001).

As a follow-up to these surveys MAF is now developing diagnostic procedures and incursion contingency plans for each of the HIEPs to improve preparedness for potential future incursions. Other counties are also developing diagnostic protocols for significant exotic pests. For example Australia has recently developed a protocol for Pierce's disease on grapes (Luck et al. 2003). Contingency planning involves developing response protocols and involvement of industry, stakeholders and other interested parties. 
TABLE 3: Extrapolated data for times (hours) and costs (\$) of a full surveillance programme with a $95 \%$ probability of finding an infected site.

\begin{tabular}{|c|c|c|c|c|c|c|}
\hline & $\begin{array}{c}\text { Sample } \\
\text { points/ } \\
\text { Site }\end{array}$ & $\begin{array}{l}\text { Minutes/ } \\
\text { sampling } \\
\text { point }\end{array}$ & $\begin{array}{c}\text { Total } \\
\text { hours } \\
\text { per site }\end{array}$ & $\begin{array}{l}\text { Total } \\
\text { sites to } \\
\text { inspect }\end{array}$ & $\begin{array}{c}\text { Time for } \\
\text { one national } \\
\text { survey }\end{array}$ & $\begin{array}{l}\text { Estimated } \\
\text { total cost }\end{array}$ \\
\hline \multicolumn{7}{|l|}{2001 Survey sites } \\
\hline Asparagus rust & 120 & 10 & 20.7 & 220 & 4554 & 598,400 \\
\hline Citrus canker & 720 & 3.1 & 38.6 & 618 & 23,855 & 300,056 \\
\hline \multicolumn{7}{|l|}{ Kanzawa mite } \\
\hline Hydrangea & 30 & 1.35 & 0.8 & 572 & 458 & \\
\hline Nashi & 90 & 2.69 & 4.31 & 63 & 272 & \\
\hline Total & & & & & 730 & 560,696 \\
\hline Karnal bunt & - & - & 0.2 & 1,800 & 360 & 310,320 \\
\hline Plum pox virus & 130 & 3.1 & 8.1 & 535 & 4334 & $2,456,393$ \\
\hline \multicolumn{7}{|l|}{2002 Survey sites } \\
\hline $\begin{array}{l}\text { Brown rot; Apple/ } \\
\text { pear rust }^{1}\end{array}$ & 210 & 3.6 & 13.5 & 1050 & 14,175 & 195,909 \\
\hline $\begin{array}{l}\text { Apple/pear rust } \\
\text { on Juniper }\end{array}$ & 90 & 1.09 & 1.9 & 86 & 163 & 1,956 \\
\hline $\begin{array}{c}\text { Total } \\
\text { Tin }\end{array}$ & & & & & & 197,865 \\
\hline \multicolumn{7}{|c|}{ Glassy-winged sharpshooter } \\
\hline Orchards & 569 & 5.25 & 50.3 & 9 & 453 & \\
\hline Nurseries & 575 & 2.34 & 22.7 & 48 & 1090 & \\
\hline Air cargo & 43 & 2.34 & 1.78 & 56 & 116 & \\
\hline Urban/rural & 64 & 2.34 & 2.6 & 2639 & 6861 & \\
\hline $\begin{array}{r}\text { Parks/reserves } \\
\text { Total }\end{array}$ & 533 & 4.16 & 37.2 & $\begin{array}{r}33 \\
9748\end{array}$ & 1228 & \\
\hline Trapping & 1948 & & & & 133 & 143,580 \\
\hline \multicolumn{2}{|c|}{ Total survey+trapping } & & & & 9881 & 84,155 \\
\hline Pierce's disease & 605 & 3.6 & 37.1 & 1081 & 40,105 & 612,202 \\
\hline $\begin{array}{l}\text { Soil-borne wheat } \\
\text { mosaic virus }^{2}\end{array}$ & 62 & 3.62 & 4.72 & 12,200 & 115,152 & $2,035,044$ \\
\hline \multicolumn{7}{|l|}{ Yellow peach moth } \\
\hline Stonefruit & 400 & 4.1 & 27.85 & 425 & 11,836 & \\
\hline Chestnut (orchard) & 400 & 9.9 & 66.55 & 250 & 16,638 & \\
\hline $\begin{array}{c}\text { Chestnut (public park) } \\
\text { Total }\end{array}$ & 5 & 42.0 & 4.05 & 300 & $\begin{array}{r}1215 \\
29.689\end{array}$ & \\
\hline $\operatorname{sed}$ & & & & & 29, & $\frac{368,182}{\text { rown rot) }}$ \\
\hline
\end{tabular}

${ }^{1}$ Estimates based on a single survey for the three pathogens (two rusts and brown rot); Juniper survey times and costs included.

${ }^{2}$ Assumed that $10 \%$ of sample points sampled and tested.

\section{ACKNOWLEDGEMENTS}

We wish to thank C. Whyte for the development of the site selection and sampling model and D. Saville, S. Wedde and C. Whyte for statistical consultations. We also wish to thank the following MAF and NPPRL people for their contributions: B. Alexander, T. Ashcroft, D. Bejakovich, G. Clover, K. Eade, D. Elliot, A. Flynn, F. Hill, P. Holder, B. Lebas, M. O'Donnell, D. Pearson, H. Pearson, J. Richmond, T. Smales and D. Voice. We thank M. Butcher (NZ Pipfruit Ltd.), M. Burns and T. Baker (NZ Grapevine Improvement Group), M. Dawkins (Summerfruit NZ), J. Kennerley (Nursery and Garden Industry Association), D. Kilnac (NZ Chestnut Counsel) and D. Steinegg (Christchurch City Council), as well as industry personnel and individual growers for allowing their crops to be surveyed. Thanks also to MAF Biosecurity Authority for funding this project and reviewing this paper. 
REFERENCES

Bejakovich, D.; Pearson, W.D.; O’Donnell, M.R. 1998: Nationwide survey of pests and diseases of cereal and grass seed crops in New Zealand. 1. Arthropods and Molluscs. Proc. $51^{\text {st }}$ N.Z. Plant Prot. Conf.: 38-50.

Braithwaite, M.; Alexander, B.J.R.; Adams, R.L.M. 1998: Nationwide survey of pests and diseases of cereal and grass seed crops in New Zealand. 2. Fungi and bacteria. Proc. $51^{\text {st }}$ N.Z. Plant Prot. Conf.: 51-59.

Crosby, T.K.; Dugdale, J.S.; Watt, J.C. 1998: Area codes for recording specimen localities in the New Zealand subregion. N.Z. J. Zool. 25: 175-183.

Dymock, J.J.; Holder, P.W.; 1996: Nationwide survey of arthropods and molluscs on cut flowers in New Zealand. N. Z. J. Crop Hort. Sci. 24: 249-257.

Lane, C.R.; Barnes, A.V.; Beales, P.A.; Griffin, R.L.; Hughes, K.J.K.; Inman, A.J.; Townend, V.C.; Brasier, C.M.; Webber, J.F. 2003: First Report of Phytophthora ramorum in the UK. Proc. $8^{\text {th }}$ Int. Cong. Plant Path.: 265.

Luck, J.; van Risjwijk, B.; Moran, J.; Merriman, P. 2003: Developing diagnostic protocols for exotic pathogens - Pierce's disease, a model. Proc. $8^{\text {th }}$ Int. Cong. Plant Path.: 58.

Navajas, M.; Gutierrez, J.; Williams, M.; Gotoh, T. 2001: Synonymy between two spider mite species, Tetranychus kanzawai and T. hydrangeae (Acari: Tetranychidae), shown by ribosomal ITS2 sequences and cross-breeding experiments. Bull. Entomol. Res. 91: 117-123.

Weinert, M.P.; Jacobson, S.C.; Grice, K.R.E.; McMichael, L.A.; Hailstones, D.L. 2001: The importance of quarantine to East Timor. Proc. $13^{\text {th }}$ Biennial Plant Path. Conf.: 77. 